\title{
REVISTAMARACANAN
}

\section{A grande reforma urbana do Rio de Janeiro e o apelo visual da urbe reformada como retórica e enlevo civilizador}

\section{The great urban reform of Rio de Janeiro and the visual appeal of the reformed metropolis as rhetoric and civilizing enchantment}

\author{
André Nunes de Azevedo \\ Universidade do Estado do Rio de Janeiro \\ andazi@bol.com.br
}

\begin{abstract}
Resumo: Entre 1903 e 1906, a Prefeitura Municipal do Rio de Janeiro levou a cabo a maior reforma urbana histórica da cidade, realizada em conjunto com o Governo Federal: a Grande Reforma Urbana do Rio de Janeiro. Nessa ação de reformulação urbana, por razões distintas, tanto o Governo Federal quanto o Governo Municipal procuraram articular um novo conjunto de imagens para a cidade por meio de suas intervenções arquitetônicas e urbanísticas. Tomando por base uma tradição de valorização da atividade estética que vinha da tradição da urbe imperial, esses governos, sobretudo o do prefeito Pereira Passos, buscaram criar, por meio do apelo visual dessas novas imagens, uma retórica de sedução que produzisse um enlevo no carioca e assim o imbuísse dos valores de civilização que desejavam inscrever no espírito desse cidadão.
\end{abstract}

Palavras-chave: Reforma urbana; Rio de Janeiro; Pereira Passos; Civilização.

Abstract: Between 1903 and 1906, the city government of Rio de Janeiro together with the Brazilian government undertook the largest urban reform in the history of the city. Building on a tradition of appreciation of aesthetic activity coming from the imperial metropolis, these governments, especially that of mayor Pereira Passos, sought to create, through the visual appeal of new images, a seductive rhetoric that generated enchantment about the city, and permeated its inhabitants of the desired values associated to Civilization.

Keywords: Urban reform; Rio de Janeiro; Pereira Passos; Civilization.

Artigo recebido para publicação em: Outubro de 2015

Artigo aprovado para publicação em: Novembro de 2015 


\section{A cultura visual no Ocidente}

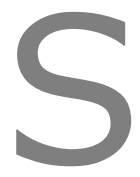

egundo Tomás de Aquino, conciliador aristotélico entre os princípios da fé e os pressupostos da razão na Europa urbana do século XIII, nada chega ao entendimento sem ter passado antes pelos sentidos. Para o autor da Suma Teológica, esses dispositivos da natureza humana seriam condição para o acesso à verdade, pois o conhecimento intelectual dependeria do conhecimento sensível. ${ }^{1}$ Assim, os sentidos seriam decisivos para o acesso à verdade. Em que pese a constatação tardia do cristianismo europeu quanto à preeminência dos sentidos para a aquisição do conhecimento ou aprendizado sobre coisa qualquer, a tradição ocidental já assumia a centralidade de um dos sentidos para o reconhecimento do mundo desde a Antiguidade grega, a saber: o sentido visual. ${ }^{2}$ Diversos mitos gregos trabalharam a visão como um dado central e determinante: é o que se passa com Orfeu, Eurídice, Narciso e Édipo, todos acometidos pela pujança desse sentido.

Segundo Marilena Chauí, a cultura ocidental tem na visão o seu principal sentido, sendo, portanto, uma cultura centrada na dimensão visual, que teria franca preeminência ante as sensações auditivas, táteis, gustativas, ou quais forem. ${ }^{3}$ O próprio universo linguístico indoeuropeu seria perpassado por essa centralidade do campo visual. Expressões como "ponto de vista", "perspectiva", "logo se vê", "algo a ver", "veja o que diz", "olhe aqui", "visões de mundo" ou "amor à primeira vista", entre outras povoam as línguas ocidentais. ${ }^{4}$ Não somente a sua centralidade, mas também a primazia sobre os demais sentidos também fica impressa em expressões linguísticas dos idiomas do Ocidente, tais como "vê como cheira", "vê como é duro" ou "vê como ressoa", ao passo que não se diz "ouve como brilha", "cheira como resplandece" ou "apalpa como cintila". ${ }^{5}$

A tradição ocidental de apelo visual também teve forte contribuição da Antiguidade romana com a arte visual arquitetônica, na qual o discurso do poder do Estado, ou mesmo do domus privado, representavam o poder patrício na cidade, constituía clara didática política não verbal, situando diferenças e hierarquias na antiga urbe latina. A preocupação da civilização romana com a imagem na cidade legou ao Ocidente do século I a.C. o livro De Architectura Libri Decem, de Marcus Vitruvius Polio, uma coleção de 10 livros que descia a especificações detalhadas de como se construir obras públicas e privadas com o que então se considerava boa arquitetura. Os 10 livros da obra tratavam a arquitetura com o cuidado de algo precioso a ser mantido. No primeiro livro, o capítulo após as laudatórias ao imperador se refere à educação do arquiteto, descrevendo a importância da formação daquele que proverá a urbe com as suas principais imagens. Depois surgem seções sobre os principais fundamentos da arquitetura, as suas divisões, a direção das ruas e os lugares para os edifícios públicos. Ao

\footnotetext{
${ }^{1}$ AQUINO, Tomás de. Suma de teologia. [Primeira parte. Questão 84]. Uberlândia: EDUFU, 2006. p115.

${ }^{2}$ Ver: CHAUÍ, Marilena. Janelas da alma, espelhos do mundo. In: NOVAES, Adauto (Org.). O olhar. São Paulo: Cia das Letras, 1998.

${ }^{3}$ Ibidem.

${ }^{4}$ Ibidem. p. 31-32.

${ }^{5}$ Ibidem. Exemplos dados pela autora. p. 39.
} 
primeiro livro seguem-se livros dedicados aos templos e aos espaços públicos, em que aparecem diversos capítulos sobre fóruns e basílicas, sobre o senado, teatros, teatros gregos, colunatas e passeios, entre outros. Também há um livro sobre cores e acabamento, demonstrando uma fina e detalhada preocupação com as imagens da urbe antiga. ${ }^{6}$ O Ocidente continuou a usar o De Architectura de Vitrúvio a cada século desde a sua publicação em 27 a.C., ${ }^{7}$ chegando a ser amplamente lido nas escolas de arquitetura do século XIX e início do XX, como na Escola Politécnica do Rio de Janeiro, que contava com um exemplar desse conjunto de 10 livros do arquiteto romano em sua biblioteca. ${ }^{8}$

Mesmo após a queda do Império Romano, no período Medieval, a preocupação com a imagem arquitetônica continuou a balizar os signos de poder, com as dimensões grandiloquentes de castelos e catedrais góticas. No entanto, a culminância do projeto ocidental de afirmação do poder da imagem urbana sobre os habitantes da cidade passou pelo Renascimento e só se concretizou no século XVII, durante o Barroco, quando a arquitetura foi utilizada para o controle do comportamento dos indivíduos na impessoalidade do crescimento acelerado das grandes cidades europeias do Seiscentos. ${ }^{9}$ Desde a experiência ocidental com o Barroco, a arquitetura se afirmou no âmbito da cultura ocidental como a principal arte visual da cidade, e os prédios e edifícios públicos mais do que nunca passaram a cumprir uma função pedagógica aos habitantes da cidade. A reforma urbana de Eugéne Haussmann, executada em meados do século XIX, criou um padrão de intervenção urbana concentrada em determinado período de tempo e buscou aprofundar o projeto ocidental de controle das populações urbanas iniciado com o Barroco.

\section{A aristocracia imperial brasileira como herdeira de uma cultura estética europeia}

Desde a chegada da Corte portuguesa em 1808, o status da cidade do Rio de Janeiro ganhou nova dimensão. De mera sede do vice-reino, vila com cerca de 50 mil habitantes, a urbe carioca passou a ser a sede do poder monárquico. Seria o início de uma vocação ao poder nobilitado que perduraria por 81 anos. Abrigar uma corte imperial demandou da cidade a constituição de instituições culturais que garantissem a reprodução do poder por parte de uma elite nobilitada e o seu autorreconhecimento por meio de códigos e práticas de legitimação socioculturais no interior de um segmento de classe social destinada à atividade econômica e à gestão política da sociedade brasileira.

\footnotetext{
6 Conforme a descrição do livro de Vitrúvio por: FILHO, Francisco Borges. O desenho e o canteiro no Renascimento Medieval (séculos XII e XIII): indicativos da formação dos arquitetos mestres construtores. São Paulo: Tese (Doutorado em Arquitetura). USP, São Paulo, 2005 (mimeo.), p. 58-63.

7 Francisco Borges Filho descreve a cada século após o I a.C. uma extensa lista de estudiosos que tomaram a obra de Vitrúvio como base, em uma lista que vai desde o século I d.C. até o século XV. Ibidem. p. 37-57.

${ }^{8}$ Ver: TELLES, Pedro Carlos da Silva. História da engenharia no Brasil. Rio de Janeiro: Clavero, 1999.

9 Cf. ARGAN, Giulio Carlo. Imagem e persuasão. Ensaios sobre o barroco. São Paulo: Cia das Letras, 2004. p. 49.
} 
Por entenderem-se herdeiras de uma tradição monárquica europeia e filiadas à cultura ocidental, as grandes figuras dos principais círculos sociais da Corte constituíram instituições de autorreconhecimento que tomavam como base as práticas e as instituições que legitimavam a vida social das altas esferas das Cortes europeias. A tradição ${ }^{10}$ aristocrática do Velho Continente, egressa do Antigo Regime, mas ainda muito viva no Oitocentos, consagrou a vida estética como elemento de autorreconhecimento e legitimação social de uma classe superior do ponto de vista do status social. Com efeito, a atividade artística, sobretudo no seu campo musical e cênico, ou os dois reunidos pela ópera, foram de grande importância na constituição de um estilo de vida que unia o cultivo da atividade estética à ideia de preservação de uma tradição de civilização remontante ao Antigo Regime em seus verdores do século XVI. ${ }^{11}$ Assim, atividades como as óperas, operetas, concertos de música, o ballet, as danças de salão, o teatro de extração francesa culta e a poesia romântica invadiram o cotidiano da elite carioca durante o Primeiro e o Segundo Reinado.

Os salões multiplicaram-se pela cidade em adição aos espetáculos de música, teatro e dança que dominaram a vida social das elites oitocentistas. Já eram existentes desde o Período Joanino, mas ganharam corpo no Segundo Reinado. Neles exibiam-se a leitura de trechos de obras de literatura francesa e poesia, a entoação de bel canto italiano, a execução de operetas ao piano e a realização de danças de salão francesas e valsas austríacas. Todas essas práticas permeadas pela conversa de salão de inspiração parisiense, em que se discutiam as novas do Velho Continente, suas mais recentes modas e as obras de literatura recém-publicadas.

Os salões, as óperas, as seções de canto e dança no Lírico ou nos demais teatros da cidade ganharam tal vulto na cultura do Segundo Reinado que:

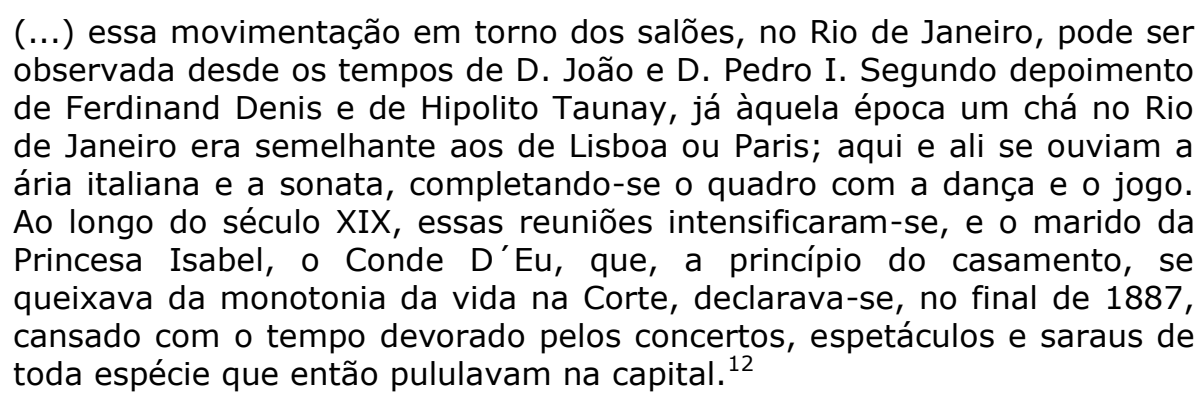

Os salões foram as principais instituições domésticas da elite carioca. Salões refinados eram dados na casa dos Haritoff, do barão de Cotegipe, do marquês de Abranches e, ainda no Período Monárquico, de Francisco Pereira Passos, onde suas filhas iam ao piano tocar trechos de óperas aos convidados. Sua indumentária era de gosto inglês, e a decoração do interior de sua casa em Laranjeiras era de inspiração francesa. ${ }^{13}$

\footnotetext{
${ }^{10}$ Cabe registrar que o sentido do termo tradição aqui utilizado é conceitual. Para Gadamer, tradição significa o fundamento da validez dos costumes e está ligada à constituição intrínseca do espírito. Ver: GADAMER, Hans G. Verdade e Método. Petrópolis: Vozes, v.1, 1997, p. 476.

11 Nossa base para essa afirmação repousa em ELIAS, Norbert. O processo civilizador. Formação do Estado e civilização. Rio de Janeiro: Zahar, 2010, v.2.

${ }^{12}$ Cf. FREIRE, Vanda Bellard. Rio de Janeiro, século XIX. Cidade da ópera. Rio de Janeiro: Garamond, 2013, p. 81.

${ }^{13}$ Cf. NEEDELL, Jeffrey. Belle Époque tropical. Rio de Janeiro: Cia das Letras, 1993, p. 107.
} 
Os salões e os concertos invadiram a vida social da urbe e, assim, permeavam o cotidiano da elite imperial. Longe de percebê-los como mera frivolidade social, cremos que os salões Oitocentistas e o cotidiano de espetáculos e concertos no Rio de Janeiro do século XIX devem ser vistos como expressão dos valores que uma camada da sociedade da Corte acalentou de maneira autêntica, e não como simples elemento simbólico de legitimação social vazio de sentido cultural. Certamente cumpriam objetivos de criar oportunidades, consolidar vínculos, pactos e fazer com que aqueles grupos se autorreconhecessem como membros distintos do corpo social brasileiro. Não obstante, foram também expressão de dada cultura que iria perder força na cidade com a Primeira República, que não descurou, no entanto, da continuidade com a prática dos salões. ${ }^{14} \mathrm{~A}$ República, mesmo com todo o seu apreço à cultura parisiense, perderia o vínculo constituído no Império entre a atividade estética e a ideia de cultivo de uma civilização. Com o novo regime, a ideia de força não mais seria alocada no campo da cultura, mas antes no campo material, com a centralidade que conferiu à ideia de progresso, que passou a subsumir a si a noção de civilização, valor maior cultivado pela elite imperial, da qual Pereira Passos fez parte de maneira ativa, como apontamos. Além de patrocinador de um dos mais reputados salões do Rio de Janeiro, Passos também se constituiu como o maior colecionador de toda a cidade, segundo Luís Edmundo, sendo o único carioca a figurar em todas as listas de principais colecionadores de pinturas, móveis antigos e objetos raros, cerâmicas, bronzes e metal em geral, vidros e cristais, joias, leques e bibelots, além de tecidos e bordados. ${ }^{15}$ Nascido em 1836, em uma fazenda na antiga cidade de São João do Príncipe, no Vale do Paraíba fluminense, Passos deixou a sua função de Prefeito do Rio de Janeiro como um ancião, aos 70 anos de idade. Esse engenheiro fez parte de uma geração da elite que acalentou a noção de construção de uma civilização no Brasil como ideal maior e como um valor profundamente vinculado à atividade estética e à sua dimensão visual.

A inserção de Pereira Passos em uma cultura de forte apreço à dimensão visual na cidade, e nela, de modo particular, à arquitetura, teve início na década de 1850 quando, em 1857, após formado em engenharia pela Escola Militar da Corte, é enviado a Paris como adido da embaixada brasileira na França. Seu pai, Antônio Pereira Passos, um grande fazendeiro de Mangaratiba, buscava com isso operar uma espécie de "correção de rumos" ante a escolha de seu filho por uma carreira de, então, baixo prestígio social. A engenharia era ocupada, via de regra, pelos extratos das camadas médias-baixas do Rio de Janeiro. Em que tenha pesado a "intenção corretiva" do pai, Francisco Pereira Passos logo tratou de fazer valer o seu diploma e partiu para atuar em algumas frentes da engenharia francesa. Vivenciou a reforma urbana de Eugéne Haussmann e viu despontar os novos edifícios da Paris reformada, junto com o seu Teatro Ópera e suas amplas avenidas arborizadas. Foi partícipe do efeito de enlevo estético da nova linguagem arquitetônica da Paris de Haussmann e Alphand. Experienciou ter seu corpo posto em uma nova escala na Paris com novas avenidas boulevares e novos prédios que despontavam em meio à malha urbana.

\footnotetext{
${ }^{14}$ Ibidem. p. 141-142.

${ }^{15}$ EDMUNDO, Luís. O Rio de Janeiro do meu tempo. Brasília: Ed. do Senado Federal, 2003, p. 212 e 213.
} 
Passos tinha plena ciência de que a reforma urbana parisiense trazia consigo um compromisso francês com a ideia de civilização como controle dos comportamentos em um meio urbano cada vez mais atomizado, que crescia exponencialmente na Europa, na esteira dos avanços da economia capitalista no Velho Continente. Sabia que a reforma urbana da capital francesa era proponente de controle humano, mas sabia também que não intentava fazê-lo somente por ampliar e retificar as vias parisienses para evitar barricadas como as de 1848, mas que, de maneira mais sutil, buscou levar a cabo esse intuito por meio do apelo a um enlevo visual que operaria como um discurso de sedução para a ordenação de novas formas de ocupação do espaço urbano. Passos percebeu que na dimensão visual da cidade residiu um apelo estético que poderia inventar novas tradições de uso do espaço urbano de uma urbe que ingressava na modernidade.

A geração de homens públicos brasileiros da qual Pereira Passos foi partícipe, e que envolvia homens como Joaquim Nabuco, o barão do Rio Branco e o visconde de Ouro Preto, foi educada no interior do discurso romântico da elite intelectual brasileira, para o qual a ideia de civilização era o valor maior a ser alcançado. ${ }^{16} \mathrm{~A}$ Europa, não resta dúvida, era o grande paradigma de civilização cosmopolita para um engenheiro formado na Escola Militar da Corte, o que não entrava em contradição com o romantismo autóctone, pois, longe de negar os novos aportes à modernidade do Velho Continente, exaltava-a como parte constitutiva a ser afirmada em um Brasil híbrido que, de forma notadamente romântica e historicista, procurava incorporar os novos elementos do moderno europeu, pondo-os em diálogo com a tradição carioca.

Passos fez parte de uma geração que não apresentou problemas com o passado nacional. Antes, de uma mirada romântica, consideravam-se herdeiros orgulhosos desse período, continuadores de uma tradição de civilização iniciada com os colonizadores portugueses e que havia resultado em uma sociedade híbrida, que entendia-se como em processo de civilização. Sua incumbência histórica: aprofundar esse processo, dando sequência a um movimento originário do interior dessa própria sociedade, mas que buscava manter um diálogo ativo com o mundo, revelando uma dimensão de cosmopolitismo em sua atuação. Esse cosmopolitismo não buscou aniquilar um passado indesejado, como o fariam os republicanos em acerto de contas com o "novo tempo da cidade". Entendiam também que o futuro do Rio de Janeiro e do Brasil não poderia ser encontrado somente no interior de suas historicidades, mas no diálogo aberto que esta deveria oferecer com as novas do Velho Mundo, vanguarda no movimento da modernidade ocidental de então.

Passos, então, fez unir o ideal de civilização de sua geração de homens públicos do Império à cultura estética vivenciada nesse período, por meio de sua participação ativa em uma nova cultura estética que Paris trazia ao Ocidente pelo resgate de uma cultura visual

\footnotetext{
${ }^{16}$ Fundamental para se ter uma dimensão da articulação entre o discurso romântico brasileiro do século XIX e a ideia de civilização é: RICUPERO, Bernardo.O romantismo e a ideia de nação no Brasil (18301870). São Paulo: Martins Fontes, 2004.
} 
europeia carreada pelo urbanismo e a arquitetura em um discurso de sedução urbanística. ${ }^{17}$ Assim, Passos, em sua ação de reformulação urbana, foi proponente da vinculação entre estética e civilização pela via da cultura visual arquitetônica. Fez isso a contrapelo das novas vinculações que se estabeleciam na República com a ideia de civilização e a entendiam como mero resultado de um desenvolvimento material postado no crescimento da economia brasileira. Como solução antitética à nova noção de civilização republicana, Passos evocou a antiga fórmula imperial que unia civilização ao desenvolvimento da cultura e da estética e fez por onde para disseminar esse antigo conceito dos tempos do Império nas novas imagens que propôs com a sua reforma urbana em plena República.

Se a dimensão de futuro da reforma urbana federal pensava o estabelecimento dessa dimensão de tempo pelo completo arrasamento do passado, que deveria ser superado por um vir a ser triunfante carreado em um crescimento econômico inexorável, a ideia de futuro acalentada por Pereira Passos operou com outra referência. Para o antigo alcaide do Rio de Janeiro, o futuro seria como uma linha que surgiria do interior de uma espiral iniciada no passado. Ou seja, o futuro seria visceral ao passado, surgiria do interior deste e seria proponente de sua atualização dialógica no tempo. Assim, o por vir de Passos nunca buscou "acertar contas" com o passado pela sua aniquilação, mas antes o englobaria e superaria em um aggiornamento em face às novidades da modernidade ocidental. Foi por sustentar essa percepção do que seria o futuro da urbe carioca que Passos tomou uma série de medidas a contrapelo da opinião pública da época, que estiveram em flagrante salvaguarda de elementos da tradição da cidade.

Desde os seus dois projetos de reforma urbana em 1875 e 1876, e mesmo quando prefeito do Rio de Janeiro entre 1903 e 1906, o engenheiro lutou para manter de pé o Morro do Castelo, ícone maior do período colonial português na cidade, sede do Conselho Municipal nos verdores desse período. O Morro do Castelo permanece firme ao cabo dos seus três grandes planos de reforma urbana. Sua derrubada não é prevista em nenhum deles. Em frente a esse morro, também em enfrentamento com a opinião pública, faz manter o Convento da Ajuda no Largo da Mãe do Bispo, atual Cinelândia, também ícone colonial, posto que era grande edificação do catolicismo luso-brasileiro do século XVIII. Na mesma região, mantém o prédio do Conselho Municipal em frente ao Teatro Municipal que construía. Sob essa decisão de manutenção pesou então grande contrariedade na opinião pública carioca, que queria vê-lo abaixo, classificando-o como "choupana colonial", ícone das origens coloniais da urbe e de seus colonizadores medievais, posto que de arquitetura portuguesa, construído em neogótico manuelino. Passos também se esforça em vão para manter de pé a Igreja Joanina de São Joaquim, na rua Larga, e o prédio do antigo Imperial Colégio D. Pedro II, monumentos que buscou preservar em sua carta cadastral, orientadora da reforma urbana do Rio de Janeiro em 1903. Já de maneira exitosa, salva o conjunto de estatuetas das musas gregas do Cais da Imperatriz, que estavam para serem destruídas pela sanha arrasadora do Clube de Engenharia

${ }^{17}$ Estamos fazendo alusão à reforma urbana de Eugéne Haussmann, iniciada na década de 50 do século XIX. 
em sua intervenção portuária. O cais fora decorado para receber a imperatriz D. Teresa em sua chegada ao Rio de Janeiro, quando seria acolhida pelo imperador D. Pedro II, sendo representamem portanto, do Império na República. Consegue realocar as estatuetas em um jardim suspenso na Gamboa, onde permanecem até hoje.

\section{O historicismo de Pereira Passos e o registro do desenvolvimento das civilizações no espaço urbano da cidade}

O apreço pela tradição é uma das facetas da cultura historicista do século XIX. Pereira Passos, que era flagrantemente historicista ${ }^{18}$ e imbuído dos valores estéticos próprios da ideia de civilização do Brasil imperial, buscou demarcar a valorização da saga de uma civilização no tempo em ação de reordenação urbana. Como cabe a um urbanista que valoriza o apelo visual de seus conceitos, Passos buscou inscrever na cidade reformada a historicidade da presença das civilizações no tempo.

Não foi sem razão que o alcaide mandou trazer em navio placas esmaltadas da Mesopotâmia, a fim de criar um salão assírio no subsolo do Teatro Municipal. A ideia de pôr um salão alusivo a uma das mais antigas civilizações no subsolo do novo teatro era fortemente metafórica e dava nota de seu historicismo oitocentista: a base, o alicerce que sustenta a civilização Ocidental atual, do qual, no entendimento de Passos, o Brasil era partícipe, era a primeira das civilizações a se desenvolver no tempo. A cumieira desse processo que se iniciara na Mesopotâmia milhares de anos antes de Cristo seria a civilização europeia, à qual, no juízo do engenheiro, o Brasil se encontraria filiado. Arte e cultura representadas pelo teatro ópera seriam os píncaros da civilização. Mas não só nessa citação se deteria o prefeito civilizador. Constrói também a Vista Chinesa no caminho para as Paineiras, no Jardim Botânico, um pagode chinês como ponto de mirada para a cidade. Ainda, temos em seu governo a construção do prédio mourisco em Botafogo, equivocadamente designado dessa forma pela sociedade carioca, pois seu estilo era uma citação de outra civilização oriental antiga, a Persa. Seu estilo arquitetônico despontando magnífico junto a Baía de Guanabara era o neopersa. Do mar nos teria vindo a civilização. Cria também um jardim suspenso na Gamboa, onde coloca quatro estátuas de musas gregas, citação do berço da civilização Ocidental, a Grécia Antiga.

Para além das iniciativas do prefeito, os coordenadores da intervenção urbana federal também buscaram operar a inscrição de civilizações antigas no espaço urbano do Rio de Janeiro. Em frente ao Palácio Monroe, no final da Avenida Central, a sua Comissão Construtora, chefiada por Paulo de Frontin, encimou a nova artéria da Capital Federal com um obelisco em pedra, símbolo da civilização egípcia. Mais do que símbolo de uma antiga e fulgurante civilização, o obelisco representava a superação historicista da sucessão progressiva das civilizações na seta do tempo. Cabe lembrar que quando Napoleão Bonaparte invade o

\footnotetext{
${ }^{18}$ AZEVEDO, André N. de. As reformas urbanas de Camilo Sitte e Pereira Passos: A modernidade do Rio de Janeiro e de Viena sob a égide da tradição. Rio de Janeiro: Revista Eletrônica Intellectus, Issn 16767640, n.2, 2009, p. 1-25.
} 
Egito, fascinado com a vigorosa expressão fálica do obelisco, manda levá-lo a Paris, a fim de fazer valer a superação do Ocidente, entendido aí como herdeiro máximo da saga das civilizações no tempo. Mesopotâmicos, persas, chineses, gregos e egípcios, todos designados no espaço urbano da urbe reformada. Da sucessão dessas diversas civilizações teriam despontado a Europa e seus afiliados no mundo. O Rio de Janeiro redesenhado por um historicista queria se marcar presente no arco dessas filiações.

\section{O apelo visual da Grande Reforma Urbana do Rio de Janeiro e sua perspectiva sedutora de enlevo estético}

Pereira Passos se distinguia da maior parte dos homens públicos do início do século XX. Nascera em 1836, no mesmo ano que o visconde de Ouro Preto, o último chefe de gabinete do Império. ${ }^{19}$ Deixaria a sua gestão como prefeito com 70 anos de idade, um ancião para os padrões da época. Portanto, Pereira Passos foi um homem formado no espírito dos valores imperiais, para o qual o valor maior a ser cultivado era a ideia de civilização. A noção de civilização acalentada no Império envolvia a construção de uma superestrutura política e jurídica consoante a arquitetura institucional dos países europeus do século XIX, uma ordem social estável, livre de erupções políticas e a afirmação de um arco de valores ligados ao universo da estética, cultura e ciência, em diálogo com a modernidade do seu tempo. Essa noção de civilização buscou afirmar uma cultura calcada na ideia de valorização da estética e na ideia de uma integração social conservadora ${ }^{20}$ em meio a uma cidade que caminhava para uma progressiva atomização com o fim da escravidão e o vertiginoso crescimento urbano então registrado.

Ainda que o horizonte de valores de um grupo de reformadores apontasse para a ideia de progresso como fim maior, e que a mirada de outros urbanizadores indicassem a busca do ideal de civilização como seu objetivo máximo, ambos convergiram quanto à estratégia para atingir os seus fins próprios. Assim, tanto a reforma urbana municipal quanto a intervenção urbana federal buscaram realizar um alto investimento no apelo estético visual como forma de seduzir o seu público-alvo a aderir à ideia de que o Rio de Janeiro, então, civilizava-se.

A iniciativa federal que mais apostou nessa estratégia foi a abertura da Avenida Central. Projetada com 33 metros de largura, aproximadamente 2.000 metros de comprimento e apresentando calçadas amplas de sete metros, a nova artéria urbana da capital da República

${ }^{19}$ Com isso busco chamar a atenção para o traço geracional de Pereira Passos, um homem criado no ethos do Império, e com significativa distância de tempo dos homens públicos que articularam a Grande Reforma Urbana do Rio de Janeiro. Sobre a relevância desse traço geracional do prefeito, ver: AZEVEDO, André N de. Da Monarquia à República. Um estudo dos conceitos de civilização e progresso na cidade do Rio de Janeiro (1868-1906). Tese (Doutorado em História). PUC-Rio, Rio de Janeiro, 2003. (mimeo.)

20 Por integração social conservadora entendemos a resistência oferecida por um segmento das elites ocidentais em face aos processos de atomização em curso com o aprofundamento do capitalismo e o vertiginoso crescimento da impessoalidade da vida urbana em fins do século XIX e início do século XX. A perspectiva de integração conservadora apela a elementos da tradição para se opor aos processos descritos, não se interessando em investir no nivelamento social, econômico e cultural das massas que se encontravam à margem desses níveis de integração. Sobre essa resistência de setores da elite ocidental, ver: BOBBIO, Norberto et al. Dicionário de política. Brasília: Senado Federal, v.1, 2010, p. 242-246. 
em muito excedia aquela que então era a mais larga avenida da cidade, por isso mesmo chamada de Rua Larga de São Joaquim. Essa artéria ia da estação de trens Central do Brasil até a Rua Camerino, onde encontrava a igreja de São Joaquim, passando a ter depois desse ponto não mais que quatro metros de largura. Cabe lembrar que antes da Grande Reforma Urbana do Rio de Janeiro a largura média das ruas do Centro da cidade era de seis metros. A nova avenida projetada pelo Ministro dos Transportes Viação e Obras Públicas, Lauro Müller, e pelo Chefe de sua Comissão Construtora, Paulo de Frontin, era de clara inspiração haussmanniana, contando com um canteiro central arborizado no melhor estilo dos boulevares parisienses. A avenida contava ainda com um Round Point, para não deixar dúvidas sobre o seu modelo de artéria urbana referente a Paris reformada. O simples fato de essa via estabelecer as suas vultuosas medidas em uma cidade que apresentava ruas acanhadas já dava nota de uma colocação do corpo do transeunte carioca em uma nova escala no Centro da cidade. Não somente a ampla largura dessa artéria lançava e redimensionava a relação com a escala urbana do carioca, mas também a natureza do conjunto edificado que surgiria com essa avenida. Para estimular os arquitetos, foi criado um concurso de fachadas, que premiou os melhores projetos. A comissão julgou cada projeto e selecionou os que consideraram adequados ao efeito visual que desejavam provocar com a Avenida Central. O resultado dessa seleção estética foi um conjunto edificado que apresentou o melhor da arquitetura eclética carioca, apresentando prédios que oscilavam entre três e cinco pavimentos, conferindo assim uma segunda diminuição do corpo do transeunte na nova escala que a ampla avenida criava com a magnificência de seus altos e imponentes prédios ecléticos, citações edificadas de uma nova imagem de civilização que o governo de Rodrigues Alves desejava fazer valer na Capital Federal.

A Avenida Central fora dividida em três seções. Na primeira, mais próxima da atual Praça Mauá, ficariam as casas de comércio e instituições financeiras. Na segunda, que partia da Rua de São Pedro, apareciam diversas instituições da sociedade civil carioca, como a Santa Casa de Misericórdia, as Veneráveis Ordens Terceiras, a Associação de Empregados do Comércio do Rio de Janeiro, o Clube de Engenharia e a sede de diversos jornais da cidade como o Jornal do Brasil, o Jornal do Commércio e O País. Na terceira parte, que ia da Rua de Santo Antônio ao final da avenida, junto a Avenida Beira Mar, encontravam-se projetadas as principais instituições icônicas da ideia de civilização e cultura na cidade. Na sua extremidade, ao lado do Convento da Ajuda, o grandiloquente Palácio Monroe, destinado à exposição Pan Americana de 1906; próximo, do outro lado da avenida, um prédio destinado aos negócios de François Hypolite Garnier, o maior livreiro da cidade; ao lado, o Palácio da Justiça Federal; em sequência, a Biblioteca Nacional; a Escola Nacional de Belas Artes e o Teatro Municipal, em frente a essa última. Além do efeito esmagador das dimensões da nova avenida, nunca antes vista na urbe carioca, e da magnitude e expressividade estética dos novos edifícios de cinco andares em um centro urbano de casebres e sobrados, acrescentar-se-ia ainda um peso simbólico de instituições icônicas da ideia de civilização: um Teatro Ópera; uma escola de pintura e escultura, a maior biblioteca do Brasil, e uma das maiores do mundo, além da sede 
da Justiça Federal. Todas essas instituições davam nota da ideia de civilização que se pretendia afirmar no espaço urbano do Rio de Janeiro.

No plano de ação da reforma urbana municipal, a finalidade maior a ser perseguida era a consecução de hábitos considerados "civilizados" na cidade. Para tanto, o prefeito Pereira Passos abre duas frentes de ação, uma primeira, que faz valer nos primeiros dias em que assume a prefeitura, é um conjunto de decretos que estabelece uma série de proibições. Assim, torna ilegal a prática de acender fogueiras nos logradouros públicos, a venda de vísceras de animais, a prática de escarrar no chão, a venda de leite retirado das vacas na porta das casas, a prática de soltar balões, de andar em pés descalços, ou de realizar o comércio ambulante, entre outras.

A segunda frente de ação do prefeito para levar a cabo o seu ideal de urbanidade e civilização é o foco do nosso interesse. Nessa iniciativa, optou por uma operação mais sutil. Funcionou no mesmo registro da estratégia aplicada pelo Governo Federal em sua iniciativa de constituição da Avenida Central. Dessa forma, Passos buscou fazer valer os valores da civilização que propugnava pela articulação de um novo arranjo urbanístico e arquitetônico para a cidade. Assim como na proposta federal que permeou a Avenida Central, o objetivo subjacente à ação urbanística de Passos era a de produzir uma nova semântica no centro urbano do Rio de Janeiro. Essa nova expressão de sentido se destinaria a produzir um enlevo de civilização por meio de uma nova sintaxe urbanística. A ideia do prefeito era tornar o Centro do Rio de Janeiro um espaço modelar da civilização, uma espécie de lugar pedagógico do "ser civilizado" a partir da exemplaridade da nova articulação arquitetônica e urbanística da cidade reformada.

Para dar validez efetiva ao Centro como um espaço a cumprir uma função pedagógica para a civilização da cidade, Passos lançou mão de uma estratégia urbanística que visou conectar o centro urbano do Rio de Janeiro com as mais diversas partes da urbe. Para isso criou três vias de ligação do Centro com os arrabaldes do subúrbio e deixou projetada uma quarta avenida - com o traçado próximo da atual Avenida Radial Oeste - com os seus estudos para execução avançados. Além disso, estabeleceu uma ligação franca com a Zona Sul, com a criação da Avenida Beira Mar, que vinculou diretamente essa área da urbe com o bairro de Botafogo. Com isso, a ideia de Passos era evocar a presença dos habitantes das mais diversas áreas da cidade no Centro. Havia na sua disposição viária uma clara convocação ao usufruto do espaço central da urbe pelos seus cidadãos.

No que diz respeito às intervenções realizadas no espaço central da cidade, cabe ressaltar algumas iniciativas do prefeito do Rio de Janeiro que dão nota de sua perspectiva de tornar esse espaço da urbe mais atrativo ao uso do cidadão carioca. Entre elas podemos destacar a reurbanização de diversas praças, com a sua valorização como lugar de encontros públicos. Nesse tipo de logradouro, o prefeito investe em aparelhagens urbanas como novas estatuárias, assentos para convivência, arborização, nova iluminação e colocação de coretos de música, que se destinavam à apresentação de bandas nos finais de semana para o entretenimento das famílias cariocas. Passos também investe em novos atrativos para a região 
central, como o aquário público de água salgada, que instalou no Passeio Público, em meio a uma série de estátuas neoclássicas; o jardim suspenso da Gamboa, com as quatro estátuas de musas gregas que salvou da demolição do Cais da Imperatriz na intervenção federal no porto, ou o teatro infantil Guignol, teatro de marionetes para as crianças que cria próximo ao Centro do Rio de Janeiro.

A construção do Teatro Municipal da cidade também deve ser vista como uma de suas iniciativas na direção da afirmação dos valores de civilização na urbe. Construído em estilo eclético, a localização que escolheu para o seu teatro ópera foi sintomática do seu projeto. Elaborou-o ao lado da já edificada Escola Nacional de Belas Artes - hoje Museu de Belas Artes -, do espaço destinado à Biblioteca Nacional e nas cercanias do Palácio Monroe e do Prédio do Supremo Tribunal Federal. Com a sua opção topológica, Passos caracterizou aquela região final da nascente Avenida Central como o espaço por excelência da exaltação dos valores da civilização na cidade: a alta cultura, por meio da ópera, dança e música erudita no Teatro Municipal, unida à pintura e escultura na Escola de Belas Artes, ladeada pela cultura e ciência representadas na Biblioteca Nacional, e pela ideia de justiça, consolidada no edifício do Supremo Tribunal Federal, todos representantes dos principais pilares da ideia de civilização. Sintomaticamente, junto a imponente arquitetura neoclássica do Teatro Monroe, encontravase o obelisco, marcando o final da nova avenida. Símbolo da civilização egípcia superada pelo Ocidente.

Com esse conjunto de iniciativas, Passos, assim como os reformadores federais, buscaram estabelecer uma retórica da sedução pela arquitetura ${ }^{21}$ e o urbanismo com o fim de criar um ambiente de enlevo civilizatório. A conjugação visual dos novos prédios, praças e avenidas do Centro lançavam o corpo do cidadão carioca a uma nova escala nesse espaço. $O$ discurso de sedução estética pela nova e grandiloquente arquitetura do Centro, valorizando aspectos centrais da ideia de civilização, como a ciência, a cultura, a arte e a justiça, foi pensado para agir de forma sedutora sobre os cidadãos do Rio de Janeiro. A ideia era que essa nova disposição arquitetônica e urbanística, realizadora de uma nova escala e proponente de novos valores na cidade, iria enlevar o carioca e permeá-lo com os valores da civilização. A nova semântica urbana da cidade reformada buscou, portanto, seduzir o cidadão a novos usos do espaço da cidade.

Não foi sem razão que o plano de reforma urbana de Pereira Passos buscou a todo tempo atrair a população carioca ao seu centro civilizador reformado. Esse objetivo do prefeito chegara a tanto que Passos inicia a construção de quatro vilas operárias, três no Centro e uma ao lado na Glória, não fosse o suficiente ter criado várias vias de ligação das mais diversas regiões com o Centro carioca.

Se o projeto conservador de integração urbana de Pereira Passos não admitia o nivelamento social e econômico, um arrojo que não cabia ao talhe do antigo prefeito também não fora de todo excludente, como uma parte da historiografia fez supor. No seu horizonte de

\footnotetext{
${ }^{21}$ A ideia de uma retórica de sedução pela arquitetura que utilizamos aqui tem por base o trabalho do arquiteto e historiador da arte Giulio Carlo Argan. Ver: ARGAN, Giulio C. Op. cit.
} 
integração, o ponto máximo de ousadia era buscar seduzir o carioca a vestir as roupas da civilização europeia traduzidas em uma linguagem carioca, como expressou a arquitetura eclética do Centro do Rio de Janeiro. Não nos resta dúvidas de que esse número não seria capaz de vestir a singularidade da tradição carioca. O prefeito, no seu afã de fazer a população olhar para a arquitetura da cidade e absorver um conceito restrito de civilização, não conseguiu compreender que o seu projeto de enlevo civilizador só estabelecia via de contato com uma parte da tradição da urbe, atinente à sua historicidade de cidade-corte. De fato, por isso, para uma parcela da sociedade, havia receptividade para o conceito de civilização que Passos tencionou fazer valer no espaço da Capital Federal. Mas o Rio de Janeiro era diverso em sua trajetória histórica. Se, por um lado, a urbe foi corte de uma casa monárquica de origem europeia, por outro, também foi a maior cidade escravista do Ocidente. Recebeu ainda um fantástico contingente de imigrantes europeus meridionais - em sua grande maioria aldeões vivenciando a sua primeira experiência urbana - e apresentou outros segmentos sociais despossuídos, deixados à própria sorte pelo darwinismo social das elites políticas da Primeira República. Esses segmentos de maior vulnerabilidade social jogavam a cada dia o jogo de sua sobrevivência, articulando-a muitas vezes no limite da reprodução biológica de sua força de trabalho, e sem certeza alguma sobre a conquista da féria de cada dia.

Pereira Passos e Rodrigues Alves realizaram um grande esforço para fazer os cariocas e brasileiros apurarem o seu sentido visual, convidando-os a olhar a cidade com maior orgulho. Passos, em particular, apostou na tradição de civilização da urbe, que vinha desde a experiência imperial. No entanto, não se deu conta de que a tradição do Rio de Janeiro não se limitava à experiência de ter sido cidade-corte. Não foi capaz de perceber que a cidade era mais do que isso. Ao não fazê-lo, foi incompreensivo com amplos setores da sociedade carioca que, embora alumbrados com o efeito estético da Grande Reforma Urbana, não se deixaram seduzir pelo enlevo civilizador projetado. Melhor seria dizer que a reforma urbana conduzida pelas duas esferas do poder público de então não se revelou capaz de seduzir essa ampla faixa da população da cidade para a sua perspectiva de civilização, pois exigia dos cidadãos uma nova educação que o Rio de Janeiro e o Brasil nunca haviam Ihes dado, já passados oitenta anos de sua emancipação política. Os limites do projeto de civilização por meio do apelo visual da urbe reformada se encontravam na assimilação de apenas um dos liames da rica e diversificada tradição da cidade do Rio de Janeiro. Passos e os reformadores federais nunca entenderam que essa cidade "eram várias", que há muito conviviam no mesmo espaço. A sua proposta de vinculação entre essas cidades pelo seu projeto de integração conservadora revelou-se menos uma ponte entre esses diversos mundos urbanos do Rio de Janeiro, e mais uma limitada admoestação para que amplas camadas da sociedade se compreendessem em uma tradição que não respondia à sua historicidade. Sob todos os sentidos que o termo porta, Passos e os demais reformadores da Grande Reordenação Urbana não compreenderam a cidade. Ao cabo de todo o esforço de persuasão estética que despenderam, não conseguiram mais que seduzir apenas uma parte dela. 
André Nunes de Azevedo: Professor Adjunto de História Moderna e Contemporânea da UERJ e Professor do Programa de Pós-Graduação da mesma instituição. Pesquisador do Laboratório de Estudos da Imigração (LABIMI) e editor associado da Revista Intellectus. Organizador do livro Rio de Janeiro: capital e capitalidade e autor de vários artigos sobre a História da Cidade, em especial a História do Rio de Janeiro. 